\title{
Planting materials for warm tropic potato production: production and field performance of nursery-produced tubers
}

\author{
J. S. BENZ $Z^{1 *}$, E. R. KELLER ${ }^{2}$ AND D. J. MIDMORE'† \\ ${ }^{1}$ International Potato Center, Apartado 5969, Lima, Peru \\ ${ }^{2}$ Swiss Federal Institute of Technology, Zurich, Switzerland
}

(Revised MS received 25 May 1995)

\begin{abstract}
SUMMARY
Potato production in the lowland tropics is constrained by lack of affordable supplies of planting material. Therefore, the potential to produce in situ tuber seed from true potato seed (TPS) seedlings and rooted stem cuttings under nursery conditions in the warm tropics was studied, and their yields were compared with those of the same materials obtained under cool conditions. Subsequently, their field performance in the warm tropics was evaluated.

Tuber yield from TPS seedlings and rooted cuttings transplanted in nursery beds under warm conditions ranged from $50 \%$ to $<20 \%$ of that obtained in cool conditions, but reductions in tuber numbers were less marked under warm conditions. Survival of seedlings was less than that of stem cuttings, but tuber numbers of seedlings exceeded those of rooted cuttings by a factor of two or more (e.g. $700 \mathrm{~m}^{-2}$ for seedlings $v .224 \mathrm{~m}^{-2}$ for rooted cuttings). Low tuber number is physiologically inherent in cuttings, as is high tuber number in seedlings. Total tuber yields varied significantly amongst clones grown in the warm climate from rooted cuttings, not always in proportion to the number of tubers produced. Differences in tuber yield and tuber number were less marked between the two TPS progenies studied.

The field comparisons highlighted the $30-40 \%$ lower yield potential for warm-climate-produced nursery seed materials. Slower emergence and fewer stems apparently were in part responsible for this effect; however, neither tuber number harvested nor the proportion of marketable tubers was affected by site of production of seed materials. Cutting medium-sized warm-produced tubers (mean $23 \mathrm{~g}$ ), the use of larger sized whole tubers $(10-20 \mathrm{~g} \mathrm{v} .5-10 \mathrm{~g})$ or increasing the planting density of $5 \mathrm{~g}$ tubers from 8.8 to 15.5 plants $\mathrm{m}^{-2}$ significantly increased yields by $4.9,2.25$ and $3.5 \mathrm{tha}^{-1}$, respectively, but yields were not increased further by $20-40 \mathrm{~g}$ tubers nor by $22 \cdot 2$ plants $\mathrm{m}^{-2}$. Small seedling tubers $(\leqslant 5 \mathrm{~g})$ can potentially lead to high stem numbers per unit weight of tubers, but their success in plant establishment was hampered in warm climates, especially in the presence of soil pathogens. Cool-climate-produced seedling tubers and tubers from cuttings can compete physiologically with field-produced seed tubers when used as planting materials in the warm tropics. However, with few exceptions, no crop from tubers produced under warm conditions could match the performance of crops from similar cool-produced tubers when planted out in the warm tropics.
\end{abstract}

\section{INTRODUCTION}

Apart from a lack of inherent tolerance to growth and yield-forming processes under high temperatures, one of the major limiting factors to potato production in warm climates is a ready supply of affordable planting

* Present address: Swiss Development Cooperation, Agricultural Service, CH-3003, Berne, Switzerland.

$\dagger$ Present address and correspondence: Department of Biology, Central Queensland University, Rockhampton, Qld 4702, Australia. material (Midmore 1992). This is particularly so if countries with limited foreign exchange have to import seed tubers. In addition, dependence upon the import of seed tubers restricts the choice of varieties to those primarily adapted to temperate, long-day conditions, which are not resistant to tropical diseases and pests.

Attempts to produce seed tubers in situ in warm climates have met with varying degrees of success. The rate of physiological decline following production and ambient storage in warm areas exceeds that in cooler climates (Midmore \& Roca 1992), which may 
be overcome to some extent through storage in cold stores (Wiersema \& Booth 1985). Short-season, heattolerant lines, which are adapted to the short, cool winters in tropical countries, were particularly susceptible to yield decline following storage and replanting, in part due to the longer storage duration between harvest and replanting (Midmore \& Roca 1992). Nevertheless, some examples where seed for warm climate production has been provided from cooler highland production do exist (e.g. in Sri Lanka; Midmore 1992), but these are the exception rather than the rule. In general, even in countries with suitable climates for highland seed production, the minor importance of lowland potato at present may not justify the investment needed to implement a conventional seed-multiplication programme.

Both minimal dependence upon imported seed (either from cool highlands or temperate countries), and the unsatisfactory performance of self-grown seed implies that lowland farmers must produce their own planting material if they are to enter into or continue with lowland potato production. Farmers have researched the use of rooted cuttings as planting material in the tropics (Vander Zaag 1987) and in a number of countries (El-Amin 1993) farmers are testing TPS technologies.

The efficiencies of producing tuber planting materials, at both warm and cool sites, based upon the use of rapid multiplication (i.e. rooted stem cuttings containing an active terminal bud) and true potato seed (TPS) technologies in nurseries are compared, and the physiological and yield performance of these materials, compared to optimal quality seed tubers, under field conditions representative of those where potato production is presently limited by cheap, good-quality seed tubers is examined. Seedlings and rooted cuttings transplanted directly to the field were also included for comparisons with the performance of seedling tubers and tubers from cuttings of the same genetic background.

\section{MATERIALS AND METHODS}

The nursery experiments were carried out at three sites within Peru between December 1985 and October 1988; Lima on the Pacific coast, Huancayo in the central highlands and San Ramon in the high jungle east of the Andes. The field evaluations of the variously produced planting materials were conducted at San Ramon. Climatic conditions are described in Table 1.

\section{Nursery experiments to produce planting materials}

In the first experimental series (Expts $1 a$ and $1 b$ ), the potential for producing tuber seed from rooted cuttings or TPS was assessed. Given that such a comparison could be biased by the different genetic background of the cutting or TPS material, the second experimental series (Expts $2 a$ and $2 b$ ) compared the performance of rooted cuttings and TPS (and apical cuttings from TPS seedlings and small seedling tubers, i.e. tubers collected from TPS seedlings) all derived from the same progenies.

Details of motherplant management, the production of rooted cuttings and TPS seedlings are presented by Benz (1989). Motherplants, originating from presprouted tubers, were from tubers planted shallow one per $1500 \mathrm{~cm}^{3}$ pot - to enhance sprout and stolon growth and to maximize lateral stem formation. The potted motherplants, grown under netting (which reduced solar radiation by $40 \%$ ) at 25 pots $\mathrm{m}^{-2}$, were decapitated at 25-30 days after planting (DAP) and the cuttings $(10 \mathrm{~cm}$ in length) were immersed in a hormone solution (Bryan et al. 1981) for $1 \mathrm{~min}$ to enhance rooting. The basal portion of the cutting was inserted into moist rooting substrate (coarse sand) at $3 \times 5 \mathrm{~cm}$ spacing, kept moist and under the same net as the motherplants, and transferred to the nursery bed 8-10 days later. At approximately weekly intervals, new axillary shoots were similarly cut to $10 \mathrm{~cm}$ in length and treated in the same way as apical cuttings. TPS, produced in Southern Chile, was treated for $24 \mathrm{~h}$ with a $1500 \mathrm{mg} \mathrm{l}^{-1}$ solution of gibberellic acid to break dormancy uniformly before sowing.

Nursery beds, in which tubers from cuttings or seedling tubers were produced, were constructed of brick or bamboo covered with plastic sheets, 10-14 m long and $1-\mathrm{m}$ wide, with a $0.6-\mathrm{m}$ walkway between beds. A 50:50 mix of sterile peatmoss: sand, $20 \mathrm{~cm}$ deep, was placed above a gravel layer. Fertilizer was then applied $\left(25-30 \mathrm{~g} \mathrm{~N}, 30-40 \mathrm{~g} \mathrm{P}_{2} \mathrm{O}_{5}\right.$ and $25-30 \mathrm{~g}$ $\mathrm{K}_{2} \mathrm{O} \mathrm{m}^{-2}$ ), with all $\mathrm{P}_{2} \mathrm{O}_{5}$ and $40 \% \mathrm{~N}$ and $\mathrm{K}_{2} \mathrm{O}$ applied before planting and the remainder in two split applications. TPS was sown in clusters of four seeds, at $1 \mathrm{~cm}$ depth, and thinned to one seedling 10 days after emergence, when shade nets were also removed. Transplanted seedlings (from TPS) or rooted cuttings were also shaded for 10 days after transplanting (DAT). Hilling was done twice (15 and 25 days after emergence or transplanting) and provided an extra 5-8 $\mathrm{cm}$ substrate. Spacing and final plant population in nursery beds varied according to experiment. Plots $\left(0.45-2 \cdot 1 \mathrm{~m}^{2}\right)$ were separated beneath the surface by plastic sheets to prevent mixing of the different treatments at harvest. Harvested areas for yield analysis were always bordered.

Stem cuttings in Expt $1 a$ (Table 2) were taken from the apical, first and second lateral cuts. Intervals between cutting were 10 days in Huancayo and 5-7 days in Lima, and the three cuts formed the basis of replications. TPS was sown when the apical cuttings were transplanted. In Expt $1 b$ (Table 2), cuttings for all replications came from the first lateral cut.

In Expts $2 a$ and $2 b$ (Table 3), using the same TPS population, seedling tubers (i.e. tubers collected from 
Table 1. Description of research sites and climatic conditions during growing seasons in Peru

\begin{tabular}{|c|c|c|c|c|c|}
\hline $\begin{array}{l}\text { Site description } \\
\text { Location }\end{array}$ & \multicolumn{2}{|c|}{ Lima } & \multicolumn{2}{|c|}{ San Ramon } & Huancayo \\
\hline Latitude & \multicolumn{2}{|c|}{$12^{\circ} 05^{\prime} \mathrm{S}$} & \multicolumn{2}{|c|}{$11^{\circ} 08^{\prime} \mathrm{S}$} & $12^{\circ} 07^{\prime} \mathrm{S}$ \\
\hline Altitude (m.a.s.1.) & \multirow{2}{*}{\multicolumn{2}{|c|}{$\begin{array}{c}240 \\
\text { Coastal desert, warm } \\
\text { summer and cool winter }\end{array}$}} & \multirow{2}{*}{\multicolumn{2}{|c|}{$\begin{array}{c}800 \\
\text { Warm mid-elevation }\end{array}$}} & 3270 \\
\hline Characterization & & & & & Cool highland \\
\hline & & & & & R giny cercon \\
\hline Growing season & $\begin{array}{l}\text { Summer } \\
\text { Jan-Apr }\end{array}$ & $\begin{array}{l}\text { Winter } \\
\text { Jun-Sept }\end{array}$ & $\begin{array}{c}\text { Dry season } \\
\text { May-Sept }\end{array}$ & $\begin{array}{c}\text { Rainy season } \\
\text { Nov-Feb }\end{array}$ & $\begin{array}{l}\text { Rainy season } \\
\text { Dec-Apr }\end{array}$ \\
\hline \multicolumn{6}{|l|}{$\begin{array}{l}\text { Climatic conditions* } \\
\text { (seasonal means) }\end{array}$} \\
\hline Maximum temperature $\left({ }^{\circ} \mathrm{C}\right)$ & $27 \cdot 7$ & $18 \cdot 9$ & $30 \cdot 1$ & $30 \cdot 8$ & $20-7$ \\
\hline Minimum temperature $\left({ }^{\circ} \mathrm{C}\right)$ & $19 \cdot 0$ & $13 \cdot 9$ & $16 \cdot 3$ & $18 \cdot 8$ & $7 \cdot 4$ \\
\hline Solar radiation ( $\mathrm{MJ} \mathrm{m}^{-2}$ day $^{-1}$ ) & $16 \cdot 4$ & $7 \cdot 3$ & $17 \cdot 8$ & $17 \cdot 1$ & $21 \cdot 0$ \\
\hline Precipitation (mm month ${ }^{-1}$ ) & 0 & 0 & 94 & 254 & 112 \\
\hline Evaporation $\left(\mathrm{mm} \mathrm{day}{ }^{-1}\right)$ & $5 \cdot 8$ & $2 \cdot 3$ & $4 \cdot 6$ & $5 \cdot 4$ & $4 \cdot 7$ \\
\hline
\end{tabular}

* Mean of three seasons at Lima-summer (1986-88); mean of two seasons at Lima-winter, San Ramon and Huancayo (1986-87/88).

Table 2. Details of experiments $(I \mathrm{a}$ and $\mathrm{lb}$ ) on the comparison of stem cuttings and seedlings for seed tuber production in nursery beds at warm and cool locations

\begin{tabular}{|c|c|c|c|c|}
\hline \multirow[b]{2}{*}{$\begin{array}{l}\text { Season } \\
\text { Location }\end{array}$} & \multicolumn{2}{|c|}{ Expt $1 a$} & \multicolumn{2}{|c|}{ Expt $1 b$} \\
\hline & $\begin{array}{l}\text { Cool } \\
\text { Huancayo } \\
\text { Nov-Mar 1985/86 }\end{array}$ & $\begin{array}{l}\text { Warm } \\
\text { Lima-summer } \\
\text { Dec-Mar 1985/86 }\end{array}$ & $\begin{array}{l}\text { Cool } \\
\text { Huancayo } \\
\text { Dec-Mar 1986/87 }\end{array}$ & $\begin{array}{l}\text { Warm } \\
\text { San Ramon } \\
\text { Apr-Jul } 1987\end{array}$ \\
\hline \multicolumn{5}{|l|}{ No of growing days } \\
\hline of cuttings & $94-111$ & $72-79$ & 95 & $70-82$ \\
\hline of seedlings & 145 & 100 & 109 & 101 \\
\hline Planting density $\left(\mathrm{m}^{-2}\right)$ & 100 & 100 & 66 & 66 \\
\hline Spacing $(\mathrm{cm})$ & $10 \times 10$ & $10 \times 10$ & $10 \times 15$ & $10 \times 15$ \\
\hline Plot size $\left(\mathrm{m}^{2}\right)$ & $0.9-1.6$ & $1 \cdot 2-1 \cdot 5$ & 0.8 & $0 \cdot 6-1 \cdot 2$ \\
\hline \multicolumn{5}{|l|}{ Treatments: } \\
\hline stem cuttings & $\begin{array}{l}\text { LT-5, Désirée, } \\
\text { Rosita }\end{array}$ & $\begin{array}{l}\text { LT-5, Désirée, } \\
\text { Rosita }\end{array}$ & $\begin{array}{l}\text { LT-5, Désirée, } \\
\text { Rosita }\end{array}$ & $\begin{array}{l}\text { LT-5, Désirée, } \\
\text { Rosita }\end{array}$ \\
\hline seedlings (TPS) & $\begin{array}{l}\text { Atz } \times \text { DTO-28 } \\
\text { Atz } \times \text { R-128.6 }\end{array}$ & $\begin{array}{l}\text { Atz } \times \text { DTO-28 } \\
\text { Atz } \times \text { R-128.6 }\end{array}$ & Atz $\times$ DTO -28 & Atz $\times$ DTO-28 \\
\hline Experimental design & $\mathrm{CRD}^{*}$ & RCBD $\dagger$ & CRD & CRD \\
\hline Number of replicates & 3 & 3 & 4 & 3 \\
\hline
\end{tabular}

* Completely randomized design.

$\uparrow$ Randomized complete block design.

seedlings) were planted to raise motherplants to produce rooted cuttings. Concurrently, TPS of the same progenies was sown twice at 10 -day intervals, the first sowing for the production of apical cuttings, the second to produce the seedlings. All cuttings and seedlings were transferred to jiffy pots to provide uniform growing conditions before transplanting them to the nursery beds. Five-gram seedling tubers, sown in nursery beds when the above were transplanted, were also used to provide single stem planting material. For Expt $2 a$, all planting materials were produced at Lima, and half were transported to San Ramon 3 days before transplanting.

The data collected included plant survival at harvest, tuber yield and graded yields, and proportions.

\section{Field performance of nursery-produced tubers}

Six field experiments were performed at the warm tropical mid-elevation site at San Ramon. Planting materials were produced beforehand in either San 
Table 3. Details of experiments (2a and $2 \mathrm{~b}$ ) on the comparison of single sprout seedling tubers, stem cuttings, apical cuttings, and seedlings from TPS-progenies

\begin{tabular}{|c|c|c|c|}
\hline \multirow[b]{2}{*}{$\begin{array}{l}\text { Season } \\
\text { Location }\end{array}$} & \multicolumn{2}{|c|}{ Expt $2 a$} & \multirow{2}{*}{$\begin{array}{l}\text { Expt } 2 b \\
\text { Warm, summer } \\
\text { Lima } \\
\text { Feb-Apr } 1988\end{array}$} \\
\hline & $\begin{array}{l}\text { Warm, dry season } \\
\text { San Ramon } \\
\text { Jul-Oct } 1988\end{array}$ & $\begin{array}{l}\text { Cool, winter } \\
\text { Lima } \\
\text { Jul-Oct } 1988\end{array}$ & \\
\hline No. of growing days & \multirow{2}{*}{\multicolumn{2}{|c|}{$100^{79}$}} & \multirow{8}{*}{$\begin{array}{l}80 \\
100 \\
10 \times 10 \\
0.30 \\
\text { Atzimba } \times \text { DTO-28 } \\
\text { Atzimba } \times \text { R } 128.6 \\
2 \text { factorial RCBD* } \\
(2 \text { progenies } \times \\
4 \text { planting materials })\end{array}$} \\
\hline Planting density $\left(\mathrm{m}^{-2}\right)$ & & & \\
\hline Spacing $(\mathrm{cm})$ & & \\
\hline Harvested plot area $\left(\mathrm{m}^{2}\right)$ & & \\
\hline Progenies & \multirow{3}{*}{\multicolumn{2}{|c|}{$\begin{array}{c}\text { Atzimba } \times \text { DTO-28 } \\
\text { CEX-69.1 } \times \text { DTO-28 } \\
2 \text { factorial } \text { RCBD* within location } \\
(2 \text { progenies } \times 4 \text { planting materials })\end{array}$}} & \\
\hline & & & \\
\hline Experimental design & & & \\
\hline Number of replicates & \multicolumn{2}{|c|}{3} & \\
\hline
\end{tabular}

* Randomized complete block design.

Table 4. Details of experiments (Expts 3a and 3b) on the comparison of warm- and cool-climate-produced planting materials

\begin{tabular}{|c|c|c|}
\hline Location and season & $\begin{array}{l}\text { Expt } 3 a \\
\text { San Ramon dry season } \\
\text { Jul-Oct } 1986\end{array}$ & $\begin{array}{l}\text { Expt } 3 b \\
\text { San Ramon dry season } \\
\text { Jul-Sept } 1987\end{array}$ \\
\hline No. of growing days & $80-102$ & 75 \\
\hline \multicolumn{3}{|l|}{ Treatments } \\
\hline Seed tubers (field) & $\begin{array}{l}\text { LT-5, Désirée, Rosita; warm and cool } \\
\text { site origins }\end{array}$ & $\begin{array}{l}\text { LT-5, Désiré; warm and cool } \\
\text { site origins }\end{array}$ \\
\hline $\begin{array}{l}\text { Tubers from cuttings } \\
\text { (nursery beds) }\end{array}$ & $\begin{array}{l}\text { LT-5, Désiré, Rosita; warm and cool } \\
\text { site origins }\end{array}$ & $\begin{array}{l}\text { LT-5, Désirée; warm and cool } \\
\text { site origins }\end{array}$ \\
\hline $\begin{array}{l}\text { Seedling tubers (TPS) } \\
\text { (nursery beds) }\end{array}$ & $\begin{array}{l}\text { Atz } \times \text { DTO-28, Atz } \times \text { R-128.6; warm } \\
\text { and cool site origins }\end{array}$ & $\begin{array}{l}\text { Atz } \times \text { DTO- } 28 ; \text { warm and cool } \\
\text { site origins }\end{array}$ \\
\hline Cuttings & LT-5, Désirée, Rosita & LT-5, Désirée \\
\hline Seedlings (TPS) & Atz $\times$ DTO- 28, Atz $\times$ R- 128.6 & Atz $\times$ DTO-28 \\
\hline Warm origin & $\begin{array}{l}\text { Lima-summer, end of March-early } \\
\text { April harvest (3-3.5 months storage) }\end{array}$ & $\begin{array}{l}\text { San Ramon rainy season, } \\
\text { Feb-March harvest } \\
\text { (4-5 months storage) }\end{array}$ \\
\hline Cool origin & $\begin{array}{l}\text { Huancayo, March harvest } \\
\text { (3.5-4 months storage) }\end{array}$ & $\begin{array}{l}\text { Huancayo, January-March } \\
\text { harvest (4-6 months storage) }\end{array}$ \\
\hline $\begin{array}{l}\text { Mean tuber weight }(g \pm \text { S.D. }) / \\
\text { seed rate }\left(\mathrm{kg} \mathrm{ha}^{-1}\right)\end{array}$ & $\begin{array}{l}\text { seed tubers: } 61 \pm 11 / 2700 \\
\text { tubers from cuttings: } 30 \pm 6 / 1300 \\
\text { seedling tubers: } 32 \pm 5 / 1400\end{array}$ & $\begin{array}{l}\text { seed tubers: } 53 \pm 8 / 2400 \\
\text { tubers from cuttings } 31 \pm 7 / 1400 \\
\text { seedling tubers } 29 \pm 1 / 1300\end{array}$ \\
\hline \multicolumn{3}{|l|}{ Plot size and spacing } \\
\hline Tubers & 80 hills, $18 \mathrm{~m}^{2}, 30 \times 75 \mathrm{~cm}$ & 60 hills, $13.5 \mathrm{~m}^{2}, 30 \times 75 \mathrm{~cm}$ \\
\hline Cuttings, seedlings & $\begin{array}{l}80 \text { hills, } 12 \mathrm{~m}^{2}, 20 \times 75 \mathrm{~cm} \\
(1 \text { cutting/hill; } 2 \text { seedlings/hill) }\end{array}$ & $\begin{array}{l}60 \text { hills, } 9 \cdot 0 \mathrm{~m}^{2}, 20 \times 75 \mathrm{~cm} \\
(1 \text { cutting } / 2 \text { seedlings } / \text { hill })\end{array}$ \\
\hline Experimental design & RCBD $^{*} ; 21$ treatments, 4 blocks & RCBD $^{*}: 16$ treatments, 4 blocks \\
\hline
\end{tabular}

* Randomized complete block design.

Ramon, Lima or Huancayo, with nursery-produced tubers from Expts 1 and 2. Optimal field management practices were employed.

Two experiments ( $3 a$ and $3 b$ ) compared the performance of five types of planting materials in the
San Ramon dry season; (1) tubers from seedlings (i.e. seedling tubers) produced in nursery beds in San Ramon and Huancayo of similar chronological age and stored at San Ramon, (2) tubers from rooted cuttings (i.e. tubers from cuttings) produced and 
Table 5. Comparison of warm climate nursery-bed-produced tubers, cool climate field-produced seed tubers (control treatment), and transplanted materials; treatments in Expt 4

\begin{tabular}{|c|c|c|c|c|c|}
\hline Planting material & Clone or progeny & $\begin{array}{l}\text { Spacing } \\
(\mathrm{cm})^{*}\end{array}$ & $\begin{array}{l}\text { Tuber weight } \\
\text { (mean g, } \pm \text { S.D.) }\end{array}$ & $\begin{array}{l}\text { Seed rate } \\
\left(\mathrm{kg} \mathrm{ha}^{-1}\right)\end{array}$ & $\begin{array}{l}\text { No. sprouts } \mathrm{m}^{-2} \\
(\text { mean } \pm \text { S.D. })\end{array}$ \\
\hline $\begin{array}{l}\text { Seed tubers, cool } \\
\text { origin (control) }\end{array}$ & $\begin{array}{l}\text { LT-5, LT-7, Désirée, } \\
\text { Serrana, Rosita }\end{array}$ & $30 \times 75$ & $58 \cdot 4 \pm 16 \cdot 6$ & 2600 & $15 \cdot 3 \pm 3 \cdot 1$ \\
\hline $\begin{array}{l}\text { Whole small tubers } \\
\text { from cuttings }\end{array}$ & $\begin{array}{l}\text { LT-5, LT-7, Désirée, } \\
\text { Serrana, Rosita }\end{array}$ & $20 \times 75$ & $9 \cdot 9 \pm 1 \cdot 1$ & 660 & $14 \cdot 3 \pm 3 \cdot 1$ \\
\hline $\begin{array}{l}\text { Cut large tubers } \\
\text { from cuttings }\end{array}$ & $\begin{array}{l}\text { LT-5, LT-7, Désirée, } \\
\text { Serrana }\end{array}$ & $20 \times 75$ & $23 \cdot 0 \pm 3 \cdot 9$ & 1500 & $9 \cdot 6 \pm 2 \cdot 4$ \\
\hline Cuttings & $\begin{array}{l}\text { LT-5, LT-7, Désirée, } \\
\text { Serrana, Rosita }\end{array}$ & $20 \times 75$ & - & - & - \\
\hline $\begin{array}{l}\text { Whole small } \\
\text { seedling tubers }\end{array}$ & Atz $\times$ DTO -28 & $20 \times 75$ & $8 \cdot 8$ & 590 & 11.9 \\
\hline Seedlings & Atz $\times$ DTO -28 & $20 \times 75$ & - & - & - \\
\hline
\end{tabular}

* 1 tuber/hill; 1 cutting/hill; 2 seedlings/hill; seed tubers 30 hills; all other treatments 45 hills/plot.

Table 6. Comparison of nursery-bed-produced tubers of different sizes and of field-produced seed tubers (control treatment) planted at a constant sprout density of 10.9 sprouts $\mathrm{m}^{-2}$; treatments in Expt 5

\begin{tabular}{|c|c|c|c|c|c|c|}
\hline Planting materials & $\begin{array}{l}\text { Tuber size } \\
\text { class }\end{array}$ & $\begin{array}{c}\text { Sprouts/ } \\
\text { tuber } \\
\text { (mean } \pm \text { s.D. })\end{array}$ & $\begin{array}{c}\text { Plant } \\
\text { population } \\
\left(\text { hill } \mathrm{m}^{-2}\right)\end{array}$ & $\begin{array}{l}\text { Within-row } \\
\text { spacing }(m)\end{array}$ & $\begin{array}{c}\text { Mean tuber } \\
\text { weight }(g) \\
\text { (mean } \pm \text { S.D. })\end{array}$ & $\begin{array}{l}\text { Seed rate } \\
\left(\mathrm{kg} \mathrm{ha}^{-1}\right)\end{array}$ \\
\hline \multicolumn{7}{|l|}{ Nursery bed tubers* } \\
\hline & $5-10 \mathrm{~g}$ & $1.47 \pm 0.25$ & 7.41 & 0.180 & $6.5 \pm 0.5$ & 480 \\
\hline & $10-20 \mathrm{~g}$ & $1.80 \pm 0.30$ & 6.06 & $0 \cdot 220$ & $13 \cdot 3 \pm 0.7$ & 810 \\
\hline \multirow{2}{*}{ Control: seed tubers $\dagger$} & $20-40 \mathrm{~g}$ & $2.17 \pm 0.24$ & $5 \cdot 03$ & 0.265 & $26 \cdot 7 \pm 1 \cdot 6$ & 1340 \\
\hline & Standard size & $2 \cdot 46 \pm 0 \cdot 27$ & $4 \cdot 44$ & 0.300 & $64 \cdot 1+11 \cdot 9$ & 2860 \\
\hline
\end{tabular}

* Tubers from cuttings of LT-5, Désirée, Rosita, and seedling tubers of Atz $\times$ DTO-28 and Atz $\times$ R-128.6 (all of warm origin).

$\dagger$ Seed tubers of LT-5, Désirée and Rosita of both cool and warm origin.

stored as for seedling tubers, (3) tubers from the field (i.e. seed tubers) similarly produced and stored as for seedling tubers, (4) TPS seedlings produced in San Ramon of the same genotypes as for seedling tubers and (5) rooted cuttings also produced in San Ramon from the same genotypes as for the tubers from cuttings and seed tubers (Table 4). Cuttings of the first lateral cut were rooted and transplanted with bare roots, while seedlings were sown 36 days before transplanting. Expt $3 b$ was harvested prematurely due to incidence of bacterial wilt.

During the Nov 1987-Feb 1988 rainy season in San Ramon, Expt 4 compared the performance of coolproduced seed tubers (i.e. the control) with warmproduced tubers from cuttings, and from seedling tubers, and cuttings and seedlings produced in situ (Table 5). A randomized complete block design with four blocks was used. Within Expt 4, larger tubers from cuttings were also cut into halves 2 weeks before planting. Since all tubers were kept in cool, diffusedlight storage (DLS) for c. 6 months, seed tubers and large tubers from cuttings were desprouted to promote multiple sprouting. Rooted cuttings and seedlings were prepared as in Expt $3 a$.

Experiment 5, which took place during the rainy season of 1987, in four randomized complete blocks, compared variously-sized tubers from cuttings and seedling tubers at within-row spacings which were inversely proportional to their tuber size (Table 6). Seedling tubers and tubers from cuttings were previously produced during the San Ramon dry season. All treatments, including warm and cool site, field-produced controls, were planted at 10.9 sprouts $\mathrm{m}^{-2}$ on the basis of actively growing sprouts counted shortly before planting. Tubers were in a suitable condition for planting, despite storage of warm- or cool-produced material in situ. Heavy precipitation caused waterlogging and three blocks only were harvested prematurely at $70 \mathrm{DAP}$.

Two experiments (Expts 6 and 7) studied the influence of seed rate (i.e. tubers from cuttings and seedling tubers selected for constant size) through 
Table 7. Details of experiments on plant population of nursery-bed-produced tubers from cuttings and seedling tubers

\begin{tabular}{|c|c|c|}
\hline Location and season & $\begin{array}{l}\text { Expt } 6 \\
\text { San Ramon rainy season } \\
\text { Dec } 1986-\text { Mar } 1987\end{array}$ & $\begin{array}{l}\text { Expt } 7 \\
\text { San Ramon dry season } \\
\text { Jul-Oct } 1988\end{array}$ \\
\hline No. growing days & $73-96$ & 78 \\
\hline Plant population (spacing) & $\begin{array}{l}8.8 \text { hills } \mathrm{m}^{-2}(0.30 \times 0.25 \mathrm{~m})^{*} \\
15.5 \text { hills } \mathrm{m}^{-2}(0.30 \times 0.14 \mathrm{~m})^{*} \\
22.2 \text { hills } \mathrm{m}^{-2}(0.30 \times 0.10 \mathrm{~m})^{*}\end{array}$ & $\begin{array}{l}4.44 \text { hills } \mathrm{m}^{-2}(0.75 \times 0.30 \mathrm{~m}) \\
6.67 \text { hills } \mathrm{m}^{-2}(0.75 \times 0.20 \mathrm{~m}) \\
8.89 \text { hills } \mathrm{m}^{-2}(0.75 \times 0.15 \mathrm{~m})\end{array}$ \\
\hline Planting materials & $\begin{array}{l}\text { Tubers from cuttings of LT-5, } \\
\text { Désirée and Rosita; } \\
\text { Seedling tubers of Atz } \times \text { DTO- } 28 \\
\text { and Atz } \times \text { R-128.6 }\end{array}$ & $\begin{array}{l}\text { Tubers from cuttings of LT-5 } \\
\text { and Désirée; } \\
\text { Seedling tubers of Atz } \times \text { DTO- } 28 \text {; } \\
\text { Controls: LT }-5 \text {, Désirée seed tubers } \\
\text { of warm and cool origin } \\
\text { (at } 4.44 \text { hill } \mathrm{m}^{-2} \text { ) }\end{array}$ \\
\hline Mean tuber weight ( $\mathrm{g} \pm$ S.D. $)$ & $5 \cdot 44 \pm 0 \cdot 17$ & $26 \cdot 3 \pm 2 \cdot 3$ (Controls: $62 \cdot 7 \pm 1 \cdot 8$ ) \\
\hline Plot size & $2 \cdot 70-3 \cdot 15 \mathrm{~m}^{-2}$ & $5.4 \mathrm{~m}^{-2}$ \\
\hline No. hills/plot & $28-60$ & $24-48$ \\
\hline Experimental design & $\begin{array}{l}\text { RCBD† split-plots, } 3 \text { blocks } \\
\text { (mainplot: planting materials; } \\
\text { subplot: plant population) }\end{array}$ & RCBD†, 13 treatments, 3 blocks \\
\hline
\end{tabular}

* Actual plant spacing within the field bed; hills $\mathrm{m}^{-2}$ calculated on the total field area including open space between field beds.

$\dagger$ Randomized complete block design.

different within-row spacings. The smallest tubers produced in nursery beds during the summer in Lima (stored 5 months in cold storage and 2 months in DLS) were planted at three within-row spacings in double-row field beds in Expt 6 (Table 7). In Expt 7, which also used tubers from nursery beds produced during the summer, the performance of medium-sized tubers grown at three within-row spacings was compared, and these were also compared with both warm- and cool-produced field seed tubers (Table 7). The lowest planting density ( 4.44 hills $\mathrm{m}^{-2}$ ) and the sizes of both nursery-bed and field-produced tubers tested in Expt 7 were equal to the planting density and tuber sizes of the respective tuber planting materials in Expts $3 a$ and $3 b$. Experiment 7 therefore served two purposes: first, to determine the response of medium-sized nursery tubers to planting density; and second, to validate, at similar seed rates, previous comparisons of nursery-bed-produced tubers with field-produced tubers of warm or cool origin.

In all seven experiments, the average tuber weight and the number of actively growing sprouts (those that showed some elongation) were determined a few days before planting. Data collection in the field included emergence, stem count (shortly after hilling), and weekly ground cover using the grid method of Burstall \& Harris (1983). Total and marketable $(>3.5 \mathrm{~cm}$ riddle) yield and tuber number, and percentage tuber dry matter (DM) were determined at harvest. Exceptions to the above were ground cover, which was not systematically taken in Expt $3 a$, and tuber DM, which was not determined in Expt 6. Total daily radiation was recorded by a Licor radiometer. The cumulative product of mean weekly ground cover estimates and weekly radiation receipts permitted calculation of intercepted radiation values throughout the total growing period. This was done for Expts $3 b$ and 5 .

Bacterial wilt damage (Pseudomonas solanacearum) was assessed in those experiments substantially affected by wilting. The number of plants with bacterial wilt symptoms was counted shortly after hilling and again towards harvest and expressed as the percentage of the total number of plants present at each observation. This was done to separate yield differences caused by bacterial wilt damage from true treatment differences, using analysis of covariance.

All tuber planting materials had a similar health status with regard to virus infection. Few visible symptoms and no noticeable differences between tuber origins or types of tuber planting materials were observed in the field, and this was confirmed by ELISA testing of leaf samples in Expt $3 b$.

\section{RESULTS}

\section{Nursery experiments}

Tuber seed production from rooted cuttings and TPS - different genetic backgrounds

Tuber yields from cuttings and seedlings were similar in Expt $1 a$ (Table 8) but were somewhat reduced at 
Table 8. Yield and yield components of cuttings and TPS in nursery beds at cool and warm locations in Expt 1 a

\begin{tabular}{|c|c|c|c|c|c|c|c|c|c|}
\hline \multirow[b]{2}{*}{$\begin{array}{l}\text { Cuttings or } \\
\text { TPS }\end{array}$} & \multicolumn{3}{|c|}{ Cool } & \multicolumn{3}{|c|}{ Warm } & \multicolumn{3}{|c|}{ Relative (warm: cool $\times 100$ ) } \\
\hline & $\begin{array}{c}\text { Yield } \\
\left(\mathrm{kg} \mathrm{m}^{-2}\right)\end{array}$ & $\begin{array}{l}\text { Tubers } \\
\left(\mathrm{m}^{-2}\right)\end{array}$ & $\begin{array}{l}\text { Mean tuber } \\
\text { weight }(\mathrm{g})\end{array}$ & $\begin{array}{c}\text { Yield } \\
\left(\mathrm{kg} \mathrm{m}^{-2}\right)\end{array}$ & $\begin{array}{c}\text { Tubers } \\
\left(\mathrm{m}^{-2}\right)\end{array}$ & $\begin{array}{l}\text { Mean tuber } \\
\text { weight }(\mathrm{g})\end{array}$ & $\begin{array}{l}\text { Yield } \\
(\%)\end{array}$ & $\begin{array}{c}\text { Tubers } \\
(\%)\end{array}$ & $\begin{array}{l}\text { Mean tuber } \\
\text { weight }(\%)\end{array}$ \\
\hline LT -5 & $9 \cdot 0$ & 150 & $58 \cdot 9$ & $3 \cdot 7$ & 135 & $27 \cdot 1$ & 41 & 90 & 46 \\
\hline Désirée & $11 \cdot 1$ & 213 & $51 \cdot 5$ & $5 \cdot 1$ & 138 & 36.9 & 46 & 65 & 72 \\
\hline Rosita & $16 \cdot 4$ & 231 & $69 \cdot 3$ & $2 \cdot 6$ & 137 & $19 \cdot 2$ & 16 & 59 & 28 \\
\hline Atz $\times \mathrm{R}-128.6$ & $13 \cdot 3$ & 683 & $19 \cdot 4$ & $2 \cdot 3$ & 245 & $9 \cdot \overline{5}$ & 18 & 36 & 49 \\
\hline Atz $\times$ DTO- 28 & $11 \cdot 1$ & 661 & 16.9 & 4.8 & 524 & $9 \cdot 3$ & 43 & 79 & 54 \\
\hline $\begin{array}{l}\text { S.E. (10 D.F. cool; } \\
8 \text { D.F, warm) }\end{array}$ & 1.49 & $23 \cdot 8$ & $3 \cdot 55$ & 0.55 & $22 \cdot 4$ & $2 \cdot 70$ & & & \\
\hline
\end{tabular}

Table 9. The main effects and some interactions of location, progeny and planting material on yield and yield components in nursery beds in Expt $2 \mathrm{a}$

\begin{tabular}{|c|c|c|c|c|c|c|c|}
\hline & \multirow{2}{*}{$\begin{array}{l}\text { Survival at } \\
\text { harvest (\%) }\end{array}$} & \multicolumn{4}{|c|}{ Total tuber yield } & \multirow{2}{*}{$\begin{array}{l}\text { Tubers } \\
\text { per plant }\end{array}$} & \multirow{2}{*}{$\begin{array}{l}\text { Mean tuber } \\
\text { weight }(\mathrm{g})\end{array}$} \\
\hline & & \multicolumn{2}{|c|}{$\left(\mathrm{kg} \mathrm{m}^{-2}\right)$} & \multicolumn{2}{|c|}{ (tubers $\mathrm{m}^{-2}$ ) } & & \\
\hline \multicolumn{8}{|l|}{ Location } \\
\hline SR dry season (warm) & $71 \cdot 4$ & \multirow{2}{*}{\multicolumn{2}{|c|}{$\begin{array}{l}3 \cdot 19 \\
6 \cdot 13\end{array}$}} & \multicolumn{2}{|c|}{310} & 4.55 & 11.9 \\
\hline Lima-winter (cool) & 80.6 & & & 5 & & $7 \cdot 19$ & $14 \cdot 4$ \\
\hline \multicolumn{8}{|l|}{ Progeny } \\
\hline CEX-69.1 × DTO-28 & $79 \cdot 0$ & \multirow{2}{*}{\multicolumn{2}{|c|}{$\begin{array}{l}4 \cdot 81 \\
4 \cdot 52\end{array}$}} & \multicolumn{2}{|c|}{497} & 6.71 & $12 \cdot 4$ \\
\hline Atz $\times$ DTO -28 & $72 \cdot 9$ & & & & 1 & 5.75 & 13.8 \\
\hline \multirow[t]{2}{*}{ S.E. ( 28 D.F.) } & 1.89 & \multicolumn{2}{|c|}{ NS } & \multicolumn{2}{|c|}{16.1} & 0.244 & NS \\
\hline & & $\begin{array}{l}\text { CEX-69.1 } \\
\times \text { DTO-28 }\end{array}$ & $\begin{array}{c}\text { Atz } \\
\times \text { DTO-28 }\end{array}$ & $\begin{array}{l}\text { CEX-69.1 } \\
\times \text { DTO-28 }\end{array}$ & $\frac{\text { Atz }}{\times \text { DTO-28 }}$ & & \\
\hline \multicolumn{8}{|l|}{ Planting material } \\
\hline Seedling tubers & 81.7 & $5 \cdot 52$ & 3.44 & 497 & 319 & 4.92 & 10.8 \\
\hline Stem cuttings & 83.6 & 5.70 & 5.99 & 208 & 240 & 2.71 & 25.8 \\
\hline Apical cuttings & 80.6 & 3.75 & 4.85 & 486 & 403 & 5.47 & 9.8 \\
\hline Seedlings & $58 \cdot 1$ & 4.04 & $4 \cdot 00$ & 746 & 654 & 11.82 & 6.0 \\
\hline S.E. $(28$ D.F. $)$ & 2.67 & \multicolumn{2}{|c|}{0.421} & \multicolumn{2}{|c|}{$32 \cdot 2$} & 0.345 & $1 \cdot 02$ \\
\hline
\end{tabular}

the warm location (Lima summer) compared to the cool (Huancayo) location. Yields of warm-climateadapted material (LT-5, Désirée and Atz $\times$ DTO-28) were less sensitive to the warm climate than were the cool-adapted material yields. In part, the shorter growth duration (by 45 days in seedlings and 22-32 days for cuttings) at the warm site was responsible for the reduced yields. Similar effects were evident in Expt $1 b$, in which yield did not differ significantly between seedlings and cuttings. On average, yields in the warm site San Ramon were less than one half of those at the cool Huancayo site (data not shown).

Total tuber number was less sensitive to the detrimental effect of high temperature (Table 8) and seedlings always produced miore tubers than did cuttings, hence mean tuber weight from seedlings at the warm site was much less than from cuttings.
Under warm conditions, relatively more small tubers $(<10 \mathrm{~g})$ were produced; for rooted cuttings the proportions of small tubers increased from $<20 \%$ in the cool site to $c .40 \%$ in the warm site, while for seedlings respective proportions were $<60 \%$ and c. $70 \%$.

Tuber production from rooted cuttings and TPSsame genetic background

As in Expts $1 a$ and $1 b$, tuber yields in Expt $2 a$ were less by $50 \%$ in the warm San Ramon than the cool Lima winter site (Table 9), and tuber numbers per unit area and per plant were also reduced. Lower survival at the warm site was evident after tuberization and was probably due to greater inter-plant competition. Differences between progenies were evident for survival and tuber number but not for tuber yield 


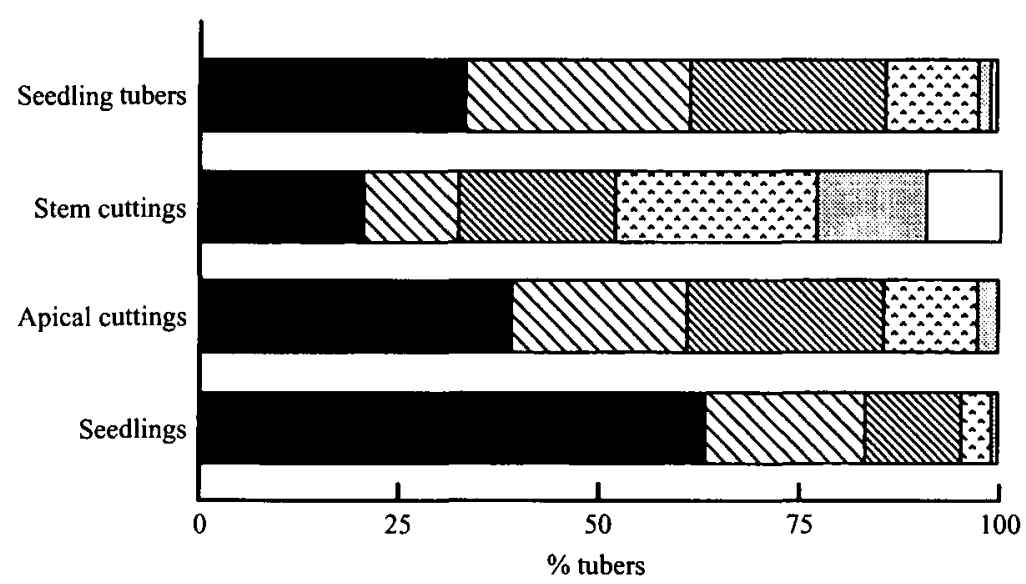

Fig. 1. The main effect of planting material on the graded yields and proportions of nursery-bed-produced tubers in six

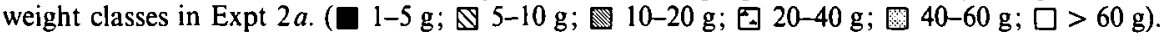

(Table 9). Across planting materials, survival of seedlings was lowest, but tuber number at $700 \mathrm{~m}^{-2}$ greatly exceeded that of other planting materials. Stem cuttings gave the greatest yield, but the least tuber number. Consequently, seedlings produced tubers with the least mean weight and stem cuttings the greatest. Stem cuttings, however, did not differ in their low tuber number across sites, whereas for the other planting materials, tuber numbers were significantly greater at the cool site (Table 9). Another interaction was evident between progeny and planting material; although tuber yield and numbers from stem cuttings, apical cuttings and seedlings did not differ between progenies (although they differed amongst themselves in the order: seedlings < apical cuttings < stem cuttings for yield; and seedlings > apical cuttings $>$ stem cuttings for tuber number), seedling tuber yield of Atz $\times$ DTO-28 was $40 \%$ less than that of CEX-69.1 $\times$ DTO-28, largely due to the production of more tubers by the latter. These interactions suggest that low tuber number is an inherent characteristic of stem cuttings, and is therefore relatively unaffected by environment and progeny. In contrast, tuber number from seedlings (although always high) and seedling tubers may show greater variation depending on environment and progeny.

In Expt $2 b$, run during the Lima summer, no difference between yields from different planting materials existed, ranging from 6.15 to $6.79 \mathrm{~kg} \mathrm{~m}^{-2}$, although survival of seedlings $(80.8 \%)$ was poorer than that of the rest $(83 \cdot 3-92 \cdot 5 \%)$. Stem cuttings, with the fewest tubers $\left(166 v .376-397 \mathrm{~m}^{-2}\right)$, had the greatest mean tuber weights $(38.4 v \cdot 16 \cdot 6-17.9 \mathrm{~g})$.

Analysis of graded yields in Expt $2 a$ highlighted the major influence of planting materials (Fig. 1); small tubers $(<10 \mathrm{~g})$ dominated the seedling harvest, while $60 \%$ of the total tuber number from stem cuttings was $\geqslant 10 \mathrm{~g}$. The percentage tubers $<10 \mathrm{~g}$ was greater at the warm site San Ramon, while the proportion of tubers $>60 \mathrm{~g}$ was greater at the cool site (data not shown). In Expt $2 b$, stem cuttings again had significantly more tubers in the weight category $>40 \mathrm{~g}$ than any other planting material $(37.5 \%$ v. $6.0-9 \cdot 8 \%)$.

\section{Field performance of nursery-produced tubers}

\section{Comparison between warm- and cool-climate- produced planting materials}

Strong tuber origin effects on total yield and its components were apparent in Expts $3 a$ and $3 b$ (Table 10 ). Overall mean yields and tuber numbers per unit area with warm-produced tuber materials were always $30-40 \%$ lower than overall mean yields and tuber numbers with cool-produced tubers.

There was no clear evidence that yields from the various types of tuber materials differed systematically with respect to their response to origin. The magnitude of differences in yield and tuber number per unit area between warm and cool origins was similar in both Expts $3 a$ and $3 b$, but reasons for this similarity differed between experiments. Yield and tuber number per plant were much less in warm- than in coolproduced materials in Expt $3 a$ while differences in plant stand between origins were relatively small (Table 10). In contrast, poor plant stand of warmorigin tuber materials was the primary cause for the differences in yield and tuber number per unit area between origins in Expt $3 b$. Warm-origin materials apparently did not compensate for the reduced plant stand by increasing yield and tuber number per plant.

Difference in final emergence (counted at 31 days after planting (DAP)) was the primary cause for the difference in plant stand at harvest in Expt $3 b$ between warm- and cool-origin tuber materials. Total emergence was better for cool-origin, field-produced 
Table 10. Effect of origin of field- (seed tubers) and nursery-bed (tubers from cuttings, seedling tubers)-produced tuber materials on yield and yield components expressed as relative means of warm versus cool tuber origins $(\mathrm{warm} / \mathrm{cool} \times 100)$

\begin{tabular}{|c|c|c|c|c|c|}
\hline & \multicolumn{2}{|c|}{ Yield } & \multicolumn{2}{|c|}{ Tubers } & \multirow{2}{*}{$\begin{array}{l}\text { Plant stand } \\
(\%)\end{array}$} \\
\hline & $\left(\mathrm{g} \mathrm{m}^{-2}\right)$ & (g hill ${ }^{-1}$ ) & $\left(\mathrm{m}^{-2}\right)$ & $\left(\right.$ hill $\left.^{-1}\right)$ & \\
\hline \multicolumn{6}{|l|}{ Expt $3 a$} \\
\hline Seed tubers ${ }^{2}$ & $52(1869 \pm 88)^{1}$ & $56(512 \pm 17)$ & $69(26 \pm 2)$ & $76(7 \cdot 1 \pm 0 \cdot 4)$ & $91(83 \pm 3)$ \\
\hline Tubers from cuttings ${ }^{2}$ & $70(1465 \pm 88)$ & $71(423 \pm 17)$ & $67(23 \pm 2)$ & $69(6.7 \pm 0.4)$ & $97(77 \pm 3)$ \\
\hline Seedling tubers ${ }^{3}$ & $60(1748 \pm 108)$ & $71(512 \pm 20)$ & $57(30 \pm 2)$ & $68(7.1 \pm 0.5)$ & $85(78 \pm 4)$ \\
\hline \multicolumn{6}{|l|}{ Expt $3 b^{4}$} \\
\hline Seed tubers ${ }^{5}$ & $69(2366 \pm 138)$ & $89(571 \pm 33)$ & $70(57 \pm 3)$ & $89(13 \cdot 8 \pm 0.8)$ & $77(94 \pm 3)$ \\
\hline Tubers from cuttings ${ }^{5}$ & $62(1772 \pm 138)$ & $98(446 \pm 33)$ & $56(36 \pm 3)$ & $88(9 \cdot 1 \pm 0.8)$ & $64(89 \pm 3)$ \\
\hline Seedling tubers ${ }^{6}$ & $86(1140 \pm 196)$ & $93(370 \pm 47)$ & $82(23 \pm 5)$ & $87(9 \cdot 0 \pm 1 \cdot 1)$ & $94(67 \pm 4)$ \\
\hline
\end{tabular}

1 Within brackets: absolute mean of cool tuber origin \pm S.E. for comparing warm and cool means ( 54 D.F. in Expt $3 a-$ some missing values estimated; 45 D.F. in Expt $3 b$ ).

2 Mean of clones LT-5, Désirée and Rosita.

3 Mean of progenies Atz $\times$ R-128.6 and Atz $\times$ DTO-28.

4 Means adjusted by covariance (covariates: $\%$ plants with bacterial wilt damage at 40 and 62 DAP).

5 Mean of clones LT-5 and Désirée.

6 Progeny Atz $\times$ DTO-28.

seed tubers of both clones ( $100 \%$ emergence) than for the respective warm-produced seed tubers. The same effect of origin on emergence was observed for tubers from cuttings and seedling tubers.

Plant stand declined after the emergence counts due to bacterial wilt damage ( $P$. solanacearum). No significant differences between tuber origin, nor types of tuber materials within clone or progeny, were observed with respect to bacterial wilt (data not presented). The clones LT-5 and Désirée were less susceptible to bacterial wilt than progeny Atzimba $\times$ DTO-28.

In contrast to yield and tuber number, traits such as percentage marketable yield and tuber dry matter content were not strongly affected by tuber origin. Both percentage marketable yield and tuber DM content averaged over all warm-produced tuber materials ( 87 and $17.8 \%$ ) were slightly less than the overall means of cool-produced tubers in Expt $3 a(90$ and $18.2 \%)$. However, these differences were significant $(P \leqslant 0.05)$.

The regressions of tuber dry weight yields on cumulative intercepted radiation for all tuber materials of Expt $3 b$ are presented in Fig. 2. Yield increased with increasing intercepted radiation. However, differences in intercepted radiation accounted for only $38 \%$ of the variation in yields across all materials. Separate regressions for cool and warm tuber origins did not improve this relationship. Regression coefficients were not statistically different for the two data sets. However, separate regressions for each clone or progeny improved the relationship between yield and intercepted radiation for clones but

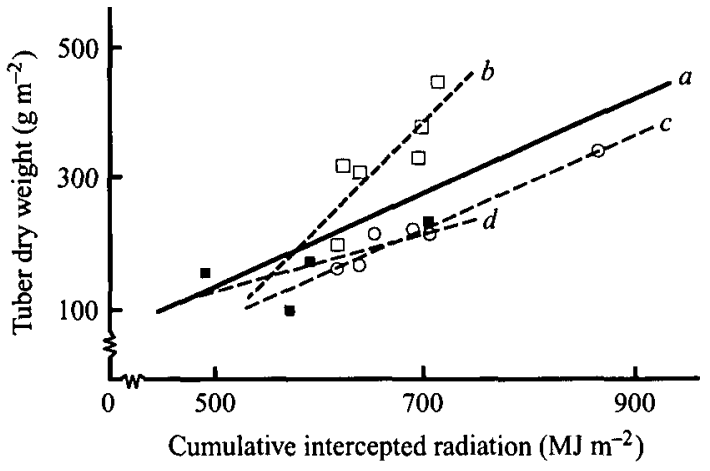

Fig. 2. Relationships between tuber dry weight and cumulative intercepted radiation for four genotypes separately and as a whole, Expt $3 b$. Line $a$ (all materials), $y=$ $0.70 x-218, r^{2}=0.38 ;$ line $b($ LT $-5, \square), y=1.57 x-718$, $r^{2}=0.69$; line $c$ (Désirée, $O$ ), $y=0.68 x-256, r^{2}=0.95$; line $d$ (Atz $\times$ DTO-28, $\square), y=0.43 x-91, r^{2}=0.31$.

not for progeny Atzimba $\times$ DTO-28. LT-5 (slope 1.57) converted intercepted radiation more efficiently to tuber dry matter than Désirée (slope 0.68).

\section{Comparison within warm-climate-produced planting materials}

Relative yields from seed tubers, tubers from cuttings, and seedling tubers were less variable across experiments than those from rooted cuttings and seedlings (data not presented). In Expt $3 a$, cuttings tuberized during the rooting period or shortly after transplanting and failed to survive. In contrast, in Expt $3 b$, 
Table 11. Effect of (a) size of nursery-bed-produced tubers, and origin effects of field-produced tubers (control treatment) in Expt 5 , planted at constant sprout density and (b) of planting density in field beds of tubers from cuttings (mean of 3 clones) and seedling tubers (mean of 2 progenies) on yield and yield components; Expt 6

(a)

\begin{tabular}{|c|c|c|c|c|c|}
\hline Treatment & $\begin{array}{l}\text { Stems } \\
\left(\mathrm{m}^{-2}\right)\end{array}$ & $\begin{array}{c}\text { Plant } \\
\text { stand at } \\
\text { harvest }(\%)\end{array}$ & $\begin{array}{c}\text { Yield } \\
\left(\mathrm{g} \mathrm{m}^{-2}\right)\end{array}$ & $\begin{array}{c}\text { Marketable } \\
\text { yield (\%) }\end{array}$ & $\begin{array}{c}\text { Tubers } \\
\left(\mathrm{m}^{-2}\right)\end{array}$ \\
\hline \multicolumn{6}{|c|}{ Nursery-bed tubers } \\
\hline $\begin{array}{l}\text { Warm origin } \\
5-10 \mathrm{~g}\end{array}$ & $12 \cdot 7$ & 53 & 776 & 62 & 29 \\
\hline $10-20 \mathrm{~g}$ & 14.7 & 67 & 998 & 69 & 29 \\
\hline $20-40 \mathrm{~g}$ & 15.5 & 76 & 1003 & 70 & 30 \\
\hline S.E. $(40$ D.F. $)$ & 0.72 & $3 \cdot 0$ & $55 \cdot 5$ & 1.7 & ns \\
\hline \multicolumn{6}{|c|}{ Control: Field tubers $\dagger$} \\
\hline Warm origin & $12 \cdot 1$ & 80 & 1008 & 73 & 28 \\
\hline Cool origin & $20 \cdot 1$ & 88 & 1364 & 76 & 35 \\
\hline S.E. $(40$ D.F. $)$ & 1.01 & NS & 78.5 & NS & NS \\
\hline
\end{tabular}

* Mean of clones LT-5, Désirée and Rosita and progenies Atz $\times$ DTO-28 and Atz $\times$ R-128.6.

$\dagger$ Mean of clones LT-5, Désirée and Rosita.

\begin{tabular}{ccccc}
\hline$(b)$ & & & \\
Plants & Yield* & Marketable \\
$\left(\mathrm{m}^{-2}\right)$ & $\left(\mathrm{g} \mathrm{m}^{-2}\right)$ & yield $(\%)$ & $\begin{array}{c}\text { Plabers* } \\
\left(\mathrm{m}^{-2}\right)\end{array}$ & $\begin{array}{c}\text { Pland at } \\
\text { harvest }(\%)\end{array}$ \\
\hline $8 \cdot 8$ & 1940 & 66 & 70 & 94 \\
$15 \cdot 5$ & 2380 & 63 & 96 & 93 \\
$22 \cdot 2$ & 2425 & 59 & 100 & 84 \\
\hline S.E. (20 D.F.) & $122 \cdot 0$ & $1 \cdot 3$ & $3 \cdot 7$ & $2 \cdot 0$ \\
\hline
\end{tabular}

* Includes all tubers $\geqslant 1 \mathrm{~g}$.

cuttings were transplanted at the optimal physiological stage and performed best among all warmclimate materials. Seedlings yielded poorly in Expt $3 b$, and their plant stand at harvest was particularly low in Expts $3 a$ and $3 b$. Furthermore, seedlings always had a significantly lower percentage marketable yield compared to that of the control (data not presented). In contrast, the percentage marketable yield of warm climate tuber materials and cuttings rarely differed significantly from that of the control.

Comparison of whole and halved tubers from cuttings

Although plant population was identical for whole (mean weight $10 \mathrm{~g}$ ) and half $(23 \mathrm{~g}$ ) tuber pieces, sprout density (sprout $\mathrm{m}^{-2}$ ) at planting was on average across clones $50 \%$ greater in the whole than halved tubers (Expt 4; Table 5), while tuber substrate per sprout was three to four times greater in the half pieces. Sprout density ranged from $8.3 \mathrm{~m}^{-2}$ in cut LT-7 tubers to $18.9 \mathrm{~m}^{-2}$ in whole small tubers of Serrana. By 36 DAP, halved tubers had similar stem populations to whole tubers $\left(12.7\right.$ and $13.0 \mathrm{~m}^{-2}$, respectively). No destructive growth analysis was undertaken, hence there was no distinction between the contribution in halved tubers of more main stems or more sprouts to total stem number. With the exception of Désirée, plant stands of cut and whole tubers did not differ significantly $36 \mathrm{DAP}$, hence it is unlikely that tuber rotting was more of a problem in the well-cured tuber pieces than in the intact tubers (data not presented).

Halved large tubers from cuttings yielded on average $400-900 \mathrm{~g} \mathrm{~m}^{-2}$ more than whole small tubers, with the exception of the generally poor-yielding Désirée. Differences between yields of cool-produced seed tubers and of cut large tubers from cuttings, despite the fact that the latter were planted at a $34 \%$ lower seed rate, did not exist (data not presented). Within a clone, there were no differences in the proportion of marketable tubers harvested from plants derived from whole small tubers, halved tubers or cool-produced seed tubers. 
Table 12. Effect of planting density of nursery bed-produced tubers, and origin effects of field-produced tubers (control treatment) in Expt 7

\begin{tabular}{|c|c|c|c|c|c|c|c|c|}
\hline \multirow[b]{2}{*}{$\begin{array}{l}\text { Clone or } \\
\text { progeny }\end{array}$} & \multirow{2}{*}{$\begin{array}{c}\text { Planting } \\
\text { density } \\
\text { (hills } \mathrm{m}^{-2} \text { ) }\end{array}$} & \multirow[b]{2}{*}{$\begin{array}{l}\text { Stems } \\
\left(\mathrm{m}^{-2}\right)\end{array}$} & \multirow{2}{*}{$\begin{array}{l}\text { Plant stand } \\
\text { at harvest } \\
(\%)\end{array}$} & \multicolumn{3}{|c|}{ Yield } & \multicolumn{2}{|c|}{ Tuber number } \\
\hline & & & & $\left(\mathrm{g} \mathrm{hill}{ }^{-1}\right)$ & $\left(\mathrm{g} \mathrm{m}^{-2}\right)$ & $\begin{array}{c}\% \\
\text { marketable }\end{array}$ & $\left(\right.$ hill $\left.^{-1}\right)$ & $\left(\mathrm{m}^{-2}\right)$ \\
\hline \multicolumn{9}{|c|}{ Nursery-bed tubers, warm origin } \\
\hline LT-5 & 4.44 & $9 \cdot 8$ & 82 & 232 & 881 & 82 & $6 \cdot 2$ & 23 \\
\hline (tubers from & 6.67 & $13 \cdot 5$ & 69 & 220 & 965 & 78 & $6 \cdot 4$ & 28 \\
\hline cuttings) & 8.89 & $19 \cdot 3$ & 75 & 189 & 1289 & 83 & $6 \cdot 1$ & 41 \\
\hline Désirée & 4.44 & $11 \cdot 3$ & 97 & 176 & 767 & 85 & $3 \cdot 6$ & 16 \\
\hline (tubers from & $6 \cdot 67$ & 17.6 & 93 & 145 & 877 & 86 & 3.6 & 22 \\
\hline cultings) & 8.89 & 17.9 & 79 & 130 & 943 & 87 & $3 \cdot 4$ & 24 \\
\hline Atz $\times$ DTO-28 & $4 \cdot 44$ & $14 \cdot 1$ & 86 & 273 & 1112 & 83 & $7 \cdot 3$ & 29 \\
\hline (seedling tubers) & $6 \cdot 67$ & $21 \cdot 0$ & 82 & 221 & 1126 & 86 & $5 \cdot 1$ & 26 \\
\hline & 8.89 & $24 \cdot 2$ & 79 & 230 & 1626 & 82 & 6.0 & 42 \\
\hline \multicolumn{9}{|c|}{ Field tubers, warm origin } \\
\hline LT-5 & 4.44 & $14 \cdot 3$ & 90 & 298 & 1174 & 82 & $8 \cdot 8$ & 35 \\
\hline Désirée & $4 \cdot 44$ & 14.8 & 92 & 138 & 548 & 75 & 4.9 & 20 \\
\hline \multicolumn{9}{|c|}{ Field tubers, cool origin } \\
\hline LT-5 & $4 \cdot 44$ & $18 \cdot 8$ & 93 & 393 & 1600 & 80 & $11 \cdot 3$ & 46 \\
\hline Désirée & 4.44 & $25 \cdot 5$ & 99 & 297 & 1289 & 83 & $7 \cdot 8$ & 34 \\
\hline S.E. $(24$ D.F. $)$ & & 2.57 & NS & $33 \cdot 2$ & 165.8 & NS & 0.82 & $4 \cdot 1$ \\
\hline
\end{tabular}

Mean tuber weight $( \pm$ S.E.): nursery-bed tubers $26 \cdot 3( \pm 2 \cdot 3) \mathrm{g}$; field tubers $62.7( \pm 1 \cdot 8) \mathrm{g}$.

\section{Effects of tuber size}

Stem population increased with increasing size of nursery-bed tubers, all planted at the same sprout density (10.9 sprouts $\mathrm{m}^{-2}$; Table 11$)$. However, this increase was entirely due to greater plant stand of larger-size nursery-bed tubers. Cool-origin, fieldproduced seed tubers had significantly more stems compared to warm-origin seed tubers which, however, cannot be explained by differences in plant stand alone.

Total yield and percentage marketable yield were significantly less in plants from 5-10 g tubers compared to $10-20$ or $20-40 \mathrm{~g}$ tubers, while tuber number remained unaffected (Table 11). Increasing tuber size from $10-20$ to $20-40 \mathrm{~g}$ or to the standard seed size $(60 \mathrm{~g}$, warm origin) did not further increase total and marketable yield. It therefore appears that, if sprout density is maintained constant, 10-20 g nursery-bed tubers can be planted at lower seed rates (weight/unit area) than larger nursery- or field-produced tubers of the same origin without yield reduction (Tables 6 and II).

\section{Effects of within-row spacing}

Main effects of planting density (i.e. within-row spacing) are presented in Table 11. Increasing planting density from 8.8 to 15.5 hills $\mathrm{m}^{-2}$ resulted in a significant yield and tuber number increase. A further increase in planting density did not result in a further significant enhancement of yield or tuber number.
Opposite trends were found for the percentage marketable yield and plant stand. No interactions between planting density and genotype were evident.

With lower planting densities ranging from 4.44 to 8.89 hills $\mathrm{m}^{-2}$ (Expt 7), stem densities from mediumsize warm-origin tubers (average weight $26 \mathrm{~g}$ ) increased almost linearly with increasing planting density (Table 12). Désirée was an exception to this trend since stem density did not further increase beyond 6.67 hills $\mathrm{m}^{-2}$. Yields $\mathrm{m}^{-2}$ were greater at 8.89 than at 4.44 hills $\mathrm{m}^{-2}$ (Table 12), although significant only for Atzimba $\times$ DTO-28 seedling tubers. Désirée tubers from cuttings showed the smallest yield response to increasing planting density and, with the exception of Désirée, there was no evidence that a plateau was reached in the response of yield to planting density. However, increased planting density tended to reduce yields per plant as a result of greater inter-plant competition. The percentage marketable yield did not differ significantly between planting densities. Tuber number per hill within clone or progeny did not differ across densities. Consequently, tuber number $\mathrm{m}^{-2}$ tended to increase with increasing planting density.

Yields from LT-5 and Désirée tubers from cuttings, planted at the highest density, did not reach the yield levels obtained with cool-produced seed tubers of the same clone (Table 12). However, seedling tubers planted at the highest density, corresponding to a seed rate of $2300 \mathrm{~kg} \mathrm{ha}^{-1}$, gave greater yields than warm field-produced seed tubers (seed rate $2800 \mathrm{~kg} \mathrm{ha}^{-1}$ ), 
although the differences were not statistically significant.

\section{DISCUSSION}

\section{Nursery experiments}

Nursery tuber yields were invariably less at the cooler than warmer production sites (Tables 8 and 9), a difference which could not always be attributed to a longer growing season (Tables 2 and 3). The use of uniform growth substrate and management practices in the nurseries removed the influence of site-related soil effects on yield. As daily irradiance was similar at both sites, the two fold or greater yield difference was possibly the combined result of reduced net assimilate available for plant growth (Midmore 1992) and reduced partitioning to the tubers (Ewing 1981) and leaves (Midmore \& Prange 1991) at the warmer site. The importance of these effects has been demonstrated by Midmore \& Roca (1992) through analysis of the contribution of cumulative intercepted radiation and the mean growing temperature to production of tuber dry weight.

Tuber number was less affected than was tuber yield by temperature across production sites (Tables 8 and 9). While it has been reported that similar tuber numbers were produced under day/night temperatures of either $30-35 / 20-25^{\circ} \mathrm{C}$ or $20-25 / 12-15^{\circ} \mathrm{C}$ (Gawronska et al. 1988) and in coastal versus highland sites in Peru (Victorio et al. 1986); in another study, plants set fewer tubers when grown at soil temperatures of $28^{\circ} \mathrm{C}$ compared to $16^{\circ} \mathrm{C}$ (Randeni \& Caesar 1984). Current theory is that warm air temperature reduces the tuberization stimulus, whereas warm soil promotes stolen growth and branching, at the expense of tuberization but potentially permitting more sites for later tuberization (Ewing \& Struik 1992). If the tuberization stimulus is sufficiently strong, then more tubers may form under warm than cool growing conditions, but if weak then fewer tubers may form.

Within a site, tuber yield did not differ between seedling or rooted cutting planting materials, but tuber number and hence mean tuber weight differed fundamentally between type of planting material. Seedlings always produced two to three times more tubers and proportionately lower average tuber weights compared to stem cuttings, whether the comparison was across genotypes (Table 8) or within the same genotype (Table 9). Cuttings, with a single node below the soil, have essentially one single locus for tuber initiation (Ewing 1981). In contrast, seedlings have many potential loci for tuberization. However, the number of loci for potential tuberization is not the only factor responsible for differences in tuber numbers between stem cuttings and seedlings (whether growing in the nursery or in the field) for the following reasons: firstly, seedling tubers set fewer tubers than seedlings (Table 9) although plants from seedling tubers also have many underground nodes. Wiersema et al. (1987) also concluded that plants grown from TPS produced more tubers per stem than those grown from microtubers in nursery beds. Secondly, apical cuttings produced twice as many tubers as stem cuttings (Table 9); however, both types of cuttings usually had only one node below the soil at transplanting. Thirdly, covering more nodes either through hilling or deeper planting (Martinez et al. 1986; Benz 1989) did not substantially increase tuber set on stem cuttings, although potentially each axillary bud along the axis represents a site for tuberization.

Seedlings, and stem cuttings of motherplants derived from large tubers, are likely to differ in their physiological condition with respect to hormone balances effecting tuberization, as discussed by Ewing (1985). Moorby (1978) stated that in most competitive situations the dominance established by the first initiated tubers would be maintained, but in most cases the first-formed tubers eventually stop growing and allow others to start. Cutter (1978) found that tubers developing from axils of cotyledons normally remain small. It is therefore possible, given the high levels of early competition in nursery beds, that the dominance of the first initiated tubers is more accentuated in stem cuttings, while the small sink size of the first tubers initiated in the axils of cotyledons allows other tubers to grow in seedlings. The role of motherplant management in conditioning the physiological status of cuttings with respect to the tuberization stimulus is discussed elsewhere (Benz et al. 1996).

Seedlings had a disproportionately high number of small tubers $<5 \mathrm{~g}$, while stem cuttings had a fairly equal proportion of tubers in each weight class, and seedling tubers and apical cuttings gave intermediate proportions (Fig. 1). This may be due to the combined effects of two processes. Firstly, plant survival at harvest was significantly lower in seedlings compared to cuttings (Table 9). Since plants from seedlings tended to die later in the season as a consequence of high levels of competition mainly for light, they may still have given some yield of predominantly small tubers. Secondly, tuber initiation in seedlings occurs over an extended period (Benz et al. 1994), but tubers initiated later would rarely grow to an appreciable size and thus late-initiated tubers would contribute to the large proportion of tubers $<10 \mathrm{~g}$.

The potential to increase the mean tuber weight and the frequency of medium-size tubers in seedlings through progeny selection seems minimal. Under warm conditions, direct field-sowing of a large number of progenies at densities comparable to those used in nursery beds yielded $260-800$ tubers $\mathrm{m}^{-2}$ (Jaworski et al. 1988). However, they reported that low tuber numbers were always associated with low yields since the average tuber weight was consistently low at $7-10 \mathrm{~g}$. At the warm location in the present study, the 
unadapted progeny Atzimba $\times \mathrm{R}-128.6$ produced fewer tubers and yielded less than Atzimba $\times$ DTO-28, while the average tuber weight and the proportion of small tubers were similar (Table 8). Lowering the planting density of seedlings seems an obvious approach to increase seedling tuber size. However, lower planting densities decreased both yield and tuber number without a significant increase in the average tuber weight (Benz 1989).

The potential to genetically increase tuber number in stem cuttings at the expense of a smaller proportion of tubers $>40 \mathrm{~g}$ also appears to be minimal. In associated studies (Benz 1989) none of the eight clones tested produced $>180$ tubers $\mathrm{m}^{-2}$ at 66 cuttings $\mathrm{m}^{-2}$, although there was genotypic variation.

It seems justifiable to conclude, therefore, that the low tuber number in stem cuttings and the large proportion of small tubers in seedlings are characteristics inherent to the type of planting material, and that this pattern is likely to be be further accentuated at lower yield levels resulting from heat stress and perhaps confounded with drought stress. The comparative efficiency under warm climates of cool or warm climate tuber seed production systems in nursery beds based either on TPS or on cuttings would largely depend on the subsequent performance of the planting materials.

\section{Field experiments}

Our data show that tuber planting materials originating from cool climates consistently gave higher yields and tuber numbers compared with those produced in warm climates, irrespective of the method of tuber planting material production. This is in agreement with results of previous experiments at the same sites using field-produced seed tubers (Wiersema \& Booth 1985; Midmore \& Roca 1992). Our nurserybed-produced tubers were produced at both cool and warm sites, however, using the same substrate and an adequate water supply and therefore differences in their yield potential can be related principally to differences in altitude and consequently in temperature.

The physiological mechanisms involved in the effects of tuber origin on subsequent yield are not well understood. One or several of the following mechanisms may explain tuber origin effects: firstly, physiological ageing of seed tubers is accelerated under warm growing and/or storage conditions (Iritani 1968; Perennec \& Madec 1980). Thus, seed tubers more rapidly reach the physiological condition where seed vigour and yield capacity decline compared to seed tubers produced and/or stored at cool temperatures. Claver (1975) found that warm-produced tubers (mean temperature $27^{\circ} \mathrm{C}$ ) reached the stage of incubation ( $50 \%$ of tubers with tuber formation on sprouts) 2 months earlier than cool- produced tubers $\left(15-20^{\circ} \mathrm{C}\right)$. Tuber origin effects would be particularly noticeable if chronologically old seed were used, since warm-produced tubers should be physiologically too old while cool-produced tubers would still be in an appropriate physiological condition. This, however, was not so in our experiments, since chronologically young and freshly sprouted tubers were used.

Secondly, tuber formation in the next generation may be influenced by 'tuber-forming substances' stored in the tubers of the parent generation (Gregory 1956; Went 1959). There is evidence that temperature during tuber growth alters endogenous hormone balances (involving gibberellins, cytokinins and abscisic acid) which control tuberization (Ewing 1987), and it might be that these effects persist and influence tuberization in the next generation. This could partly explain why low yields per plant from warm-origin tuber planting materials were always associated with fewer tubers per plant.

Thirdly, differences in yield potential may be due to differences in seed tuber composition and reserves (Davies 1984) manifest in the dry matter content (Wiersema \& Booth 1985). Our warm-origin tuber materials generally had low dry matter contents at harvest (LT-5 16-17\%, Desiree 15\%) which were c. $20-25 \%$ lower than those attainable at the cool highland site. It has been reported that total sprout length per tuber decreased with decreasing tuber dry matter content (Wurr 1980) which in turn may have reduced the emergence and thus final plant stand of crops from warm-origin tubers in the present experiments.

Yields from all types of tuber planting materials (i.e. seed tubers, seedling tubers and tubers from cuttings) were influenced by their site of production in a similar way. There was no evidence to suggest that warm, nursery-bed-produced tubers had a higher yield potential than warm, field-produced seed tubers. However, nursery bed tuber seed production may still be advantageous for reasons related to efficiency of production (multiplication rate), disease management and the scope for their off-season protected production.

Yields from rooted cuttings and seedlings produced in situ at the warm site were limited primarily by their poor plant stand (Benz 1989; Benz et al. 1995). Survival of cuttings was dependent upon their physiological condition, particularly whether they were induced to tuberize before transplanting. However, with cuttings of an appropriate physiological condition as produced in Expt $3 b$ (i.e. no tuber initiation during rooting period nor shortly after transplanting), total yields were as great as those of any warm-climate-produced material. Poor survival of seedlings was often related to the incidence of damping off caused mainly by Rhizoctonia solani (Benz 1989) and exacerbated by high soil temperature 
(Elango 1986), although the importance of transplant shock and poor root regeneration cannot be ruled out.

To improve the multiplication rate of nursery-bedproduced materials, particularly from cuttings, some tubers were halved before planting. In comparison with whole small tubers from cuttings, halved large tubers from cuttings yielded on average $43 \%$ more. Since sprout density (sprouts $\mathrm{m}^{-2}$ ) is negatively associated with tuber size (Wiersema \& Cabello 1986), in order to have at least one actively growing sprout per tuber piece, half tubers had to be large and required an extra $840 \mathrm{~kg} \mathrm{ha}^{-1}$ seed rate compared to whole small tubers (Table 5). However, the increased seed rate was more than compensated for by the extra yield obtained (i.e. $840 \mathrm{~kg} \mathrm{ha}^{-1}$ increase in seed rate gave on average a yield increase of $7900 \mathrm{~kg} \mathrm{ha}^{-1}$ ). Therefore, cutting large tubers improved the efficiency of the seed system based on the production of tubers from cuttings in nursery beds. Halved, warm-origin large tubers gave yields statistically similar to whole cool-origin large seed tubers, even though the latter were planted at a $70 \%$ greater seed rate. These results corroborate those of Allen (1979). In addition to reducing the quantity of planting material needed, cutting tubers has the advantage of breaking dormancy and reducing apical dominance. Cutting tubers enhances sprouting and emergence, particularly in physiologically young tuber seed (Iritani 1968). In Expt 4, stem number per sprout for tuber pieces was double that for either whole small or whole large tubers.

Given that seedlings produced large numbers of small tubers in nursery beds (Table 9), it was necessary to show that the field use of small tubers could lead to an efficient multiplication ratio (i.e. ratio of harvested to planted tuber weight). Whereas the multiplication ratio was greatest for low seed rates (e.g. ratio of 16 at $480 \mathrm{~kg}$ seed ha ${ }^{-1}$ to 8 at $1340 \mathrm{~kg} \mathrm{ha}^{-1}$ in Expt 5), and has been shown to be greatest for the smallest-size of nursery-bed-produced seedling tubers (Wiersema \& Cabello 1986), the use of small tubers and low populations did not permit efficient use of field space for the production of the ware potato crop (Table 11). Small tubers had a good capacity to produce stems (Table 11), but their yield potential is closely dependent upon the growing environment (Engels et al. 1993). Plant stand decreased with decreasing tuber size (Table 11), most likely due to limited amounts of tuber reserves per stem, which negatively affected rate of emergence under high soil temperature. The smallest tubers from nursery production should therefore be re-used as further planting material in the nursery production cycle (as in Expt $2 a$; Table 9). With larger sized tubers (c. $20 \mathrm{~g}$ ), yields continued to increase with planting density two or four times the norm for traditional potato cultivation (Table 11 and 12) and economic considerations will dictate the planting rate to be chosen.

In conclusion, cool-climate production of nurserybased planting materials, as for field-based seed systems, led to greater productivity both in terms of production of seed or seedling tubers and in their subsequent potential to produce high-yielding crops in warm climates. Cuttings and seedlings produced fewer and smaller tubers in nurseries in the warm than cool climate. However, manipulation of the tubers from cuttings by halving tubers or by planting more tubers from cuttings of seedlings led to greater yields, although they did not often match those of seed tubers imported from the cool climate.

We thank field staff at the three CIP research stations for their competent assistance.

\section{REFERENCES}

Allen, E. J. (1979). Effects of cutting seed tubers on number of stems and tubers and tuber yields of several potato varieties. Journal of Agricultural Science, Cambridge 93, 121-128.

Benz, J. S. (1989). Alternative propagation systems for warm climate potato production. Doctor Tech. Sci. dissertation, Swiss Federal Institute of Technology, Zurich, Switzerland.

Benz, J. S., Keller, E. R. \& Midmore, D. J. (1995). Planting materials for warm tropic potato production: growth and yield of transplanted seedlings or rooted cuttings and tuber materials in the field. Field Crops Research 40 , 179-192.

Benz, J. S., Keller, E. R. \& Midmore, D. J. (1996). Plant materials for warm tropic potato production: motherplant management for the production of rooted cuttings. Tropical Agriculture, Trinidad.

Bryan, J. E., JaCkson, M. T. \& Melendez, N. G. (1981). Rapid multiplication techniques for potatoes. A Bulletin of the International Potato Center, Lima, Peru.
Burstall, L. \& Harris, P. M. (1983). The estimation of percentage light interception from leaf area index and percentage ground cover in potatoes. Journal of Agricultural Science, Cambridge 100, 241-244.

Claver, F. K. (1975). Influence of temperature during the formation of potato tubers and its effects on the first progeny. Phyton 33, 1-6.

CuTter, E. G. (1978). Structure and development of the potato plant. In The Potato Crop: The Scientific Basis for Improvement (Ed. P. M. Harris), pp. 70-152. London: Chapman and Hall.

Davies, H. V. (1984). Mother tuber reserves as factors limiting potato sprout growth. Potato Research 27, 209-218.

El-Amin, S. M. (1993). True potato seed based potato technology for the Sudan. PhD dissertation, University of Helsinki, Finland.

Elango, F. (1986). The role of high soil temperatures in the damping-off of true potato seedlings in the lowland tropics. Tropical Agriculture (Trinidad) 63, 66-67. 
Engils C., El Bedewy, R. \& Sattelmacher, B. (1993). Effects of weight and planting density of tubers derived from true potato seed on growth and yield of potato crops in Egypt. 2. Tuber yield and tuber size. Field Crops Research 35, 171-182.

EwING, E. E. (1981). Heat stress and the tuberization stimulus. American Potato Journal 58, 31-49.

Ewing, E. E., (1985). Physiological studies with cuttings. In Potato Physiology (Ed. P. H. Li), pp. 156-207. London: Academic Press.

EwING, E. E. (1987). The role of hormones in potato tuberization. In Plant Hormones and their Role in Plant Growth and Development (Ed. P. J. Davies), pp. 515-538. Dordrecht: Martinus Nijhoff.

Ewing, E. E. \& Srruik, P. C. (1992). Tuber formation in potato: induction, initiation and growth. Horticultural Reviews 14, 89-198.

Gawronska, H., Thornton, M. K. \& Dwelle, R. B. (1988). Effect of high temperature on tuber initiation and growth. American Potato Journal 65, 479 (Abstract).

GREGORY, L. E. (1956). Some factors for tuberization in the potato plant. American Journal of Botany 43, 281-288.

IrITANI, W. M. (1968). Factors affecting physiological aging (degeneration) of potato tubers used as seed. American Potato Journal 45, $111-116$.

Jaworski, C. A., Phatak, S. C., Ghate, S. R. \& Gitaitis, R. D. (1988). Cultural practices in use of true seeds of potato and screening of tuber-forming Solanum species under hot climatic conditions. HortScience 23, 500-504.

Martinez, O., Chao, R. \& Perrera, J. L. (1986). Estudio preliminar en la profundidad de plantacion de esquejes en papa (Solanum tuberosum). Ciencias Tecnicas Agricolas (Cuba) 5, 39-44.

Midmore, D. J. (1992). Potato production in the tropics. In The Potato Crop: The Scientific Basis for Improvement (Ed. P. M. Harris), pp. 728-793. London: Chapman and Hall.

Midmore, D. J. \& Prange, R. K. (1991). Sources of heat tolerance amongst potato cultivars, breeding lines, and Solarum species. Euphytica 55, 235-245.
Midmore, D. J. \& RoCA, J. (1992). Influence of production and storage conditions on subsequent growth and tuber yield of potato (Solanum spp.) in the hot tropics. Journal of Agricultural Science, Cambridge 119, 45-58.

MoORBY, J. (1978). The physiology of growth and tuber yield. In The Potato Crop: The Scientific Basis for Improvement (Ed. P. M. Harris), pp. 189-205. London: Chapman \& Hall.

Perennec, P. \& Madec, P. (1980). Age physiologique du plant de pomme de terre. Incidence sur la germination et répercussions sur le comportement des plantes. Potato Research 23, 183-199.

Randen, G. \& Caesar, K. (1984). Die Entwicklung der Kartoffelpflanze (Solanum tuberosum L.) unter dem Einfluss verschiedener Bodentemperaturen II. Die Knollenentwicklung. Z. Acker- und Pflanzenbau 153, 129-135.

VANDER ZAAG, P. (1987). Developments in potato production techniques in Asia. Acta Horticulturae 213, 79-90.

Victorio, R. G., Moreno, U. \& Black, C. C., JR (1986). Growth, partitioning, and harvest index of tuber-bearing Solanum genotypes grown in two contrasting Peruvian environments. Plant Physiology 82, 103-108.

WENT, R. W. (1959). Effects of environment of parent and grandparent generations on tuber production by potatoes. American Journal of Botany 46, 277-282.

Wiersema, S. G. \& BoOTH, R. H. (1985). Influence of growing and storage conditions on the subsequent performance of seed potatoes under short-day conditions. Potato Research 28, 15-25.

Wiersema, S. G. \& Cabello, R. (1986). Comparative performance of different-sized seed tubers derived from true potato seed. American Potato Journal 63, 241-249.

Wiersema, S. G., Cabello, R., Tovar, P. \& Dodds, J. H. (1987). Rapid seed multiplication by planting into beds micro tubers and in vitro plants. Potato Research 30, 117-120.

WurR, D. C. E. (1980). The influence of the specific gravity and node of origin of potato tubers on sprout growth. Potato Research 23, 95-103. 